\title{
OBITUARIES
}

\section{Prof. T. S. Wheeler}

All who had ever met Thomas S. Wheeler, professor of chemistry in University College, Dublin, will have been deeply grieved to hear of his sudden and unexpected death on December 13 within a few hours of having attended a meeting at the College of Pharmacy. His untimely passing at the age of sixty-three is a tragic loss to the University College where he was not only an outstanding scientist and administrator but also a personal friend respected by everyone who, in whatever capacity, worked or studied there.

Although his work for the College over nearly eighteen years must remain unfinished, Prof. Wheeler has by his energy, his passion for progress, and his genius for inspiring others, much more than fulfilled his own modest ambition to leave the department better than he found it. It is much to be regretted that he has not lived to see the completion of the new ehemistry department, now under construction, to the planning of which he had devoted much time and thought. His work for chemistry, for scientific education in Ireland and in other fields will long be recalled. Not least will he be missed by the Irish Government, which frequently sought his advice on practical scientific problems, advice which he was uniquely able to give owing to his remarkably wide interests in science, combining as he did extensive knowledge and research interests in all branches of chemistry and even in physies and mathematies. Prof. Wheeler endeared himself to all by his understanding, his humour, and his felicity of phrase.

Prof. Wheeler was born in Dublin in 1899. He was educated at O'Connell Schools and received a scholarship which enabled him in 1916 to proceed to the Royal College of Science for Ireland, where he gained the associateship in chemistry in 1920. $\mathrm{He}$ became for one year a demonstrator and research worker at the Royal Technical College in Glasgow, where his work gained him the external Ph.D. degree of the University of London. In 1923 he was appointed a research chemist at Woolwich Arsenal, and during 1928-31 was a senior chemist at the Winnington Research Laboratories of Imperial Chemical Industries, Ltd.

Prof. Wheeler left industry in 1931 to become for seven years principal and professor of organic chemistry at the Royal Institute of Science, Bombay, where he was active in building up flourishing schools of teaching and research and starting a postgraduate Department of Chemical Technology. He returned to Ireland in 1938 as State chemist in charge of the State Laboratories, and was appointed to the chair of chemistry in University College, Dublin, in 1945. Prof. Wheeler was the author, or joint author, of some two hundred original papers, patents, articles, and books, on an extraordinarily wide range of topics, the largest single group being on the organic chemistry of flavonoids and related compounds. Prof. Wheeler gave freely of his time in the service of many important committees and his loss will be keenly felt not only in Ireland and Great Britain but also in India and the United States, where he had many warm personal contacts. $\mathrm{H}_{\theta}$ is survived by his wife, whom he married in 1926, a son and two daughters. W. BAKER

\section{Dr. J. S. Greenhow}

THE death of Dr. J. S. Greenhow on November 3 at the early age of thirty-four has brought to an untimely end the career of a leading exponent of the study of the upper atmosphere by radar methods. In the span of twelve years he published nearly forty important research papers, and for most of these he was either the sole author or the leader of the research.

A graduate of the University of Manchester, he began his research work at Jodrell Bank in the early years of meteor observations by radar methods. He became interested in the characteristies of the meteoric ionization and the factors controlling the movement, diffusion and decay of the meteor trails. Observation of the motion of meteor trail echoes proved to be the best method for studying winds in these regions of the upper atmosphere. In this way, Dr. Greenhow obtained detailed information of wind speeds and directions, diurnal variations, turbulence and so on. Further knowledge of the conditions in the upper atmosphere came from the rates of decay of meteor echoes, and these were used to derive the atmospheric densities and temperatures. The initial stages of trail formation then attracted his attention, and he also studied how echo properties vary with the radar wavelength.

In 1960, Dr. Greenhow joined the Royal Radar Establishment at Malvern. Here he made the first meteor observations obtained at a wave-length as short as $25 \mathrm{~cm}$. The results strikingly confirmed the view he had expressed previously, that a meteor trail has a surprisingly large initial radius, of the order of a metre. At the short wave-lengths, the trail also generally appears as only a short column of ionization close to the meteor. More recently, he has led the first British experiments to investigate upper atmosphere ionization by the important method, discovered in the United States, of measuring the radio scattering by free electrons at the short wavelengths which penetrate through the ionosphere. $\mathrm{H}_{\Theta}$ completed his last paper, "The Electron Scattering Cross Section in Incoherent Backscatter", just before his last brief illness. He had given no hint to his colleagues that for more than a year previously he had known that he might not have long to live.

All Dr. Greenhow's work was characterized by directness of approach, elegance of experimental techniques, and elarity of analysis, so that valuable and interesting results followed from every investigation. He was extremely capable in all stages of a research, from designing and constructing apparatus to the writing of the final report. He had a purposeful and stimulating enthusiasm which made him an inspiring team leader. At the same time, he was modest and friendly, and he is greatly missed by his colleagues. He leaves a widow and a daughter.

$$
\text { J. S. HEY }
$$

\section{Mr. Herbert Womersley}

Herbert Womersley, a distinguished student of the taxonomy of the Acarina and primitive insects, died in Adelaide on October 14, 1962, at the age of seventy-three.

$\mathrm{He}$ was born in Warrington, Lancashire, on April 10, 1889, the son of amateur lepidopterist, Fred Womersley. $\mathrm{He}$ trained as an industrial chemist in soap and chemical manufacturing, specializing in fuel economy and water softeners. In his youth he became an amateur entomologist with a leaning to microscopy, getting training from Abraham Flatters in Manchester, and publishing an early paper in Flatters' journal, The Micrologist, on the use of terpineol. In 1914 he joined the Royal Army Medical Corps, and later transferred to the Chemical Corps, Royal Engineers, in one of the British Gas Companies, seeing service on the Western Front. In 1917 he was transferred back to Great Britain in explosives manufacture. In 1920 he moved from Warrington to Bristol as a departmental manager of Christopher Thomas and 